\title{
Incidental lesions following bilateral nephrectomy of adult polycystic kidneys
}

\author{
M.I. Bellini, F .Dor, J. Cambell, P. Brookes, P. Hill, V. Papalois
}

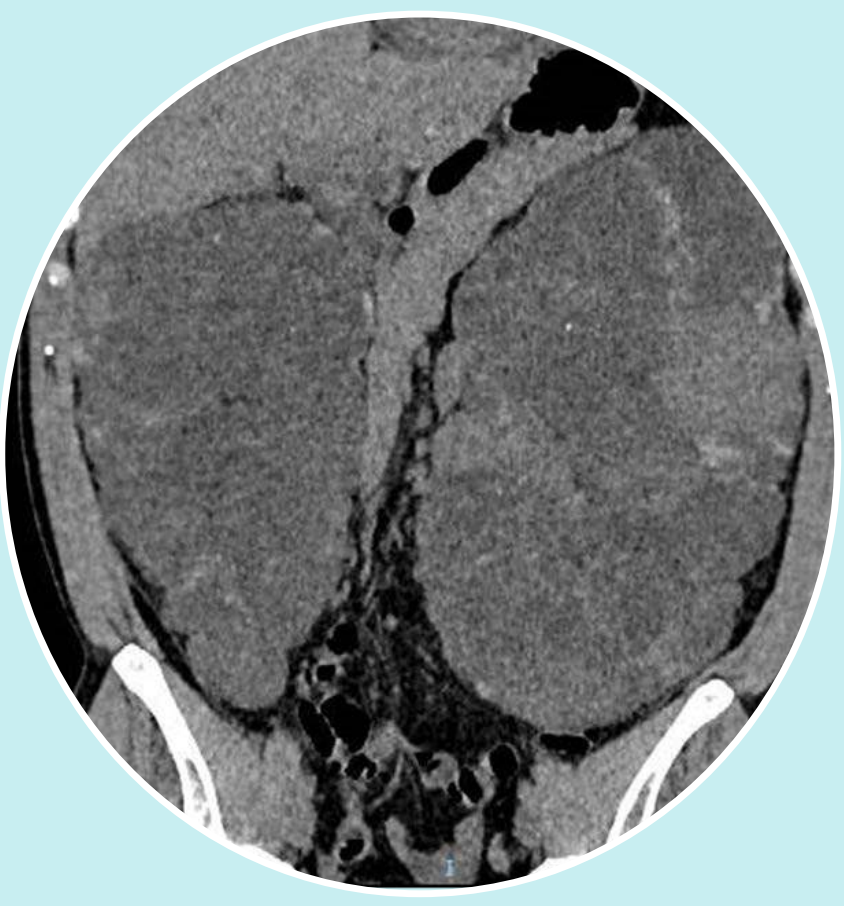

Background: Is there an association between incidental renal neoplasm and autosomal dominant polycystic kidney disease (ADPKD) in end stage renal failure (ESRF) population?

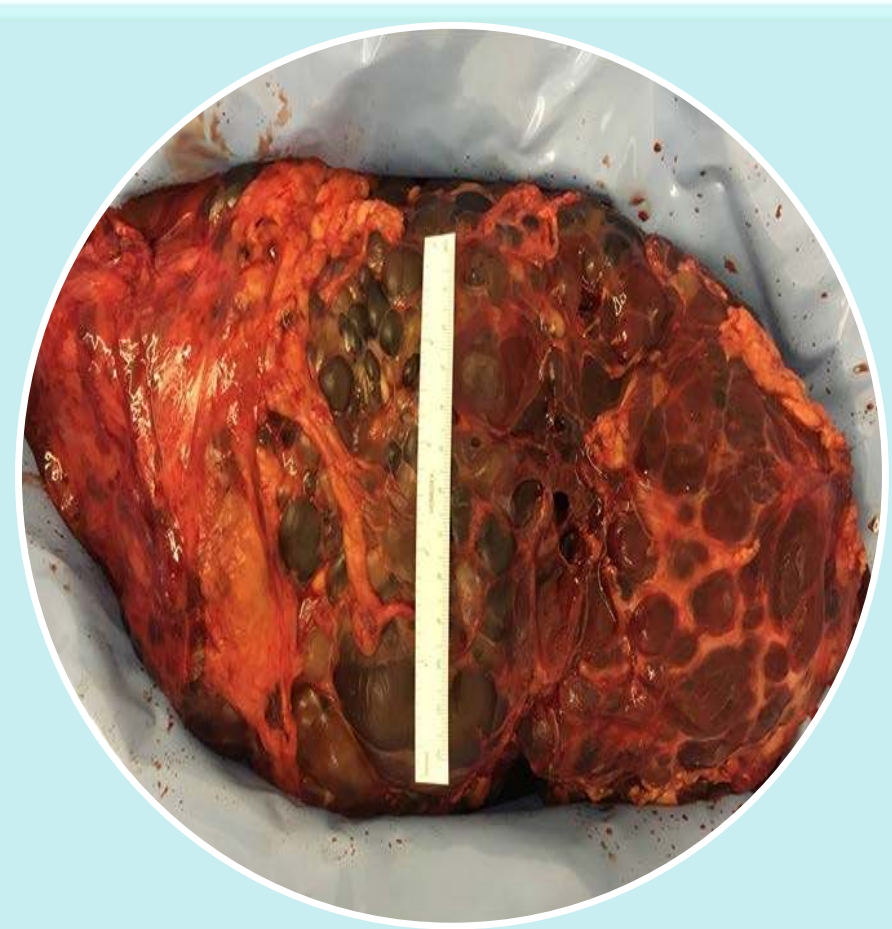

Methods: Retrospective analysis from a prospective maintained database of the consecutive native nephrectomies in ADPKD

patients. Surgery was performed at our institution via midline laparotomy, prior or after kidney transplant in the period between 2012 and 2016

\section{Results}

$$
\text { Male }=10 / 21(48 \%)
$$

Previous kidney transplant $=9 / 21(43 \%)$

Median age $=54.5$ years $(36-68)$

Median hospital stay $=9$ days $(6-20)$

Indication for surgery: space (62\%), recurrent cyst infection (38\%), pain/discomfort (24\%), haematuria (19\%) and weight loss $(5 \%)$.

PRA changes: $1 / 21 \quad(p<0.01)$

Median follow-up: 14 months (2-36). All patients alive

Histology: 4 incidental lesions (19\%): 3 papillary adenomas (14\%) and $1 \mathrm{pT} 1 \mathrm{a}$ papillary renal cell carcinoma $(5 \%)$.

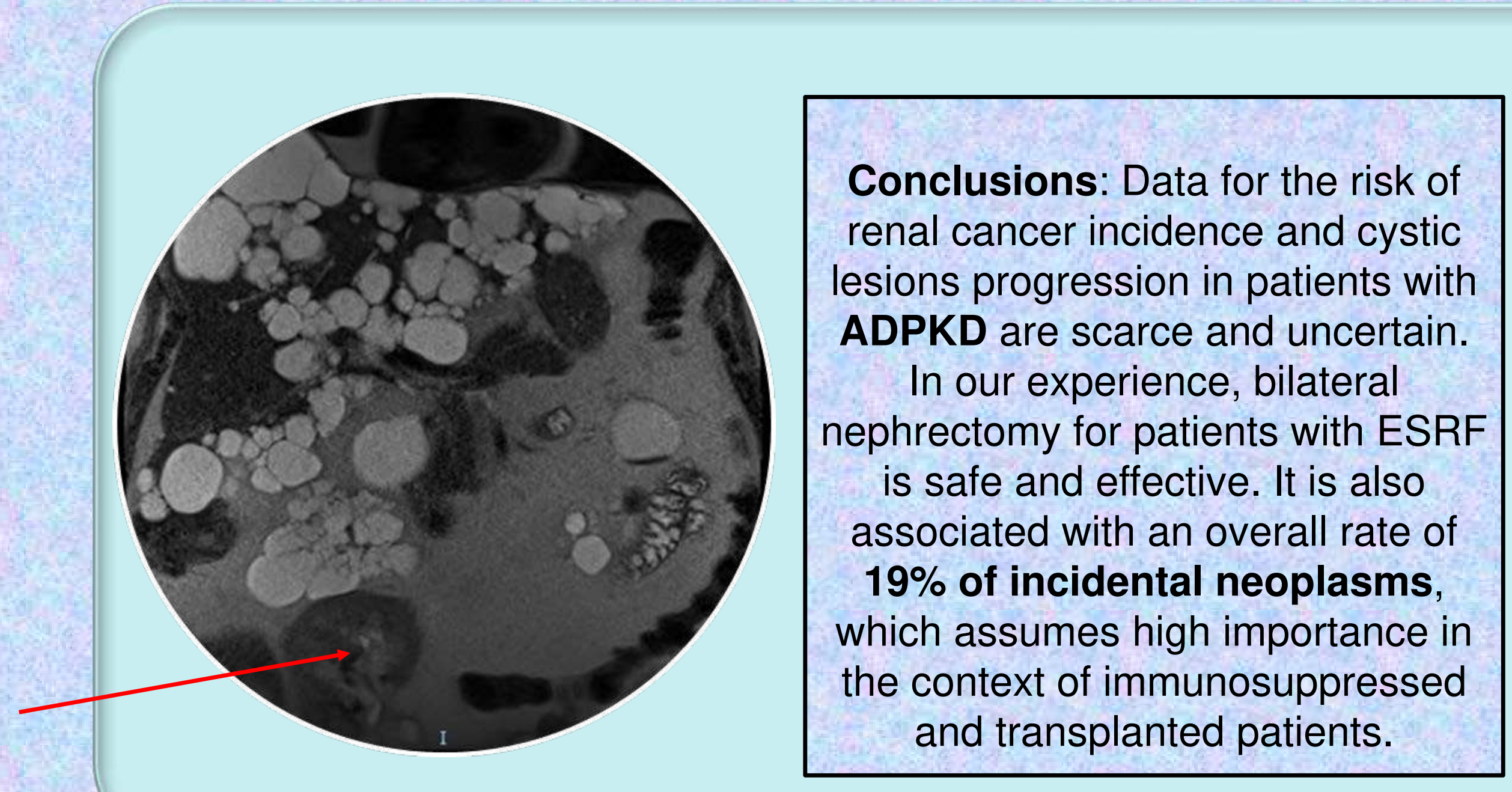

